\section{Sources of Whitefly (Homoptera: Aleyrodidae) Resistance in Citrullus for the Improvement of Cultivated Watermelon}

\author{
Alvin M. Simmons and Amnon Levi \\ U.S. Department of Agriculture, Agricultural Research Service, U.S. Vegetable \\ Laboratory, 2875 Savannah Highway, Charleston, SC 29414
}

Additional index words. breeding, germplasm, genetics, vegetable, Bemisia tabaci, Bemisia argentifolii

\begin{abstract}
The B-biotype sweetpotato whitefly, Bemisia tabaci (Gennadius), feeds on and damages numerous vegetable crops including watermelon (Citrullus sp.). Seven watermelon cultivars, a triploid line, and 16 U.S. Plant Introduction accessions (PIs) of C. lanatus var. lanatus; 10 PIs of $C$. lanatus var. citroides; and eight PIs of $C$. colocynthis, were evaluated for resistance to $B$. tabaci. Bioassays were based on nonpreference and performance of the whiteflies on the 42 Citrullus genotypes. Most of the watermelon cultivars and C. lanatus PIs tested were highly susceptible to whitefly infestation, while the $C$. colocynthis accessions exhibited whitefly resistance. Among the $C$. colocynthis accessions tested, PI 386015, PI 386018, and PI 386024 were most resistant to $B$. tabaci. This study identified useful sources of germplasm that can be used for the improvement of watermelon for resistance to whiteflies.
\end{abstract}

Whiteflies are destructive insect pests of horticultural crops worldwide. Their threat to vegetable crops has been exacerbated over the past decade because of the rapid emergence of the B-biotype sweetpotato whitefly, Bemisia tabaci (Gennadius) [U.S. Dept. of Agriculture (USDA), 1997]. The taxonomic status of this pest is under debate as to whether it merits a species status as $B$. argentifolii Bellows and Perring (Perring et al., 1993), or is one of multiple biotypes of $B$. tabaci (Brown et al. 1995). Regardless of its taxonomic classification, it is an important pest worldwide. It is more virulent than the A-biotype of $\mathrm{B}$. tabaci (Cock, 1993; USDA, 1997), and feeds on a wider range of plant species than what was previously known for Bemisia (Cock, 1993; Simmons et al., 2000). Like many vegetable crops, watermelon [Citrullus lanatus (Thunberg) Matsum. \& Nakai var. lanatus] is an excellent host for B. tabaci (Ghong, 1969; Greathead 1986; Simmons, 1994).

Watermelon accounts for $2 \%$ of the vegetable production area in the world and is grown in 44 states in the United States (USDA, 1999). The largest U.S. watermelon production areas are in Florida, California, Texas, Georgia, and Arizona. U.S. watermelon production increased from $1.2 \mathrm{t}$ in 1980 to $3.7 \mathrm{t}$ in 1998 with an at-farm value of $\$ 284$ million (USDA, 1999). The cultivated watermelon belongs to $C$. lanatus var. lanatus, which thrives in West Africa. This species includes $C$. lanatus var. citroides ("preserving melon") that is grown in Southern Africa where

Received for publication 2 Jan. 2001. Accepted for publication 12 Sept. 2001. This article reports the results of research only. Mention of a proprietary product does not constitute an endorsement or recommendation by the USDA for its use. it is called "tsamma" melon (Whitaker and Bemis, 1976). The genus Citrullus Schrad. ex Eckl \& Zeyh. contains three additional known diploid species: 1) C. colocynthis (L.) Schrad ("bitter apple"), a perennial species grown in sandy areas throughout northern Africa, southwestern Asia, and the Mediterranean (Burkill, 1985; Zamir et al., 1984; Jarret et al., 1997); 2) C. ecirrhosus Cogn., a perennial wild species (Meeuse, 1962); and 3) C. rehmii De Winter, an annual wild species (De Winter, 1990). The last two species are endemic to the desert regions of Namibia (Meeuse, 1962).

Insecticides are the primary remedial control tactic for managing whiteflies. However, most of these insecticides also kill whitefly predators (Lazarre and Gerling, 1993) and parasitoids (Simmons and Jackson, 2000). Because of concerns with reliance on insecticides for insect management, it is essential that other control tools be available for a sound whitefly management scheme. Of the other control tools, host plant resistance is the most fundamental and desirable tool. Although many high quality watermelon cultivars were developed during the last century, there is still an ongoing need to enhance disease and pest resistance of this crop. Whitefly resistance was reported in Cucumis melo L. (Riley et al., 2001; Simmons and McCreight, 1996; Soria et al., 1999), and Cucurbita (McAuslane et al., 1996; Wessel-Beaver, 2000). However, there have not been any reports on screening Citrullus germplasm for resistance to whiteflies. The Citrullus collection at the USDA, Agricultural Research Service (ARS), Plant Genetic Resources Conservation Unit, Griffin, Ga., includes 1600 U.S. Plant Introduction accessions (PIs). Of these, 1480 are C. lanatus var. lanatus, 102 are $C$. lanatus var. citroides, and
18 are $C$. colocynthis. The objective of our study was to evaluate germplasm of these three groups in an effort to identify potential sources that could be used in the improvement of watermelon for whitefly resistance.

\section{Materials and Methods}

Source of insects. Whiteflies used in the study were from a colony of B-biotype $B$. tabaci which originated from a feral population on sweetpotato Ipomea batatas (L.) in 1992. Thereafter, the insects were reared continuously on uncaged assorted vegetables (Simmons, 1994) in a greenhouse section. Each year, supplemental feral B-biotype $B$. tabaci from sweetpotato were added to the colony.

Plant material. The study included seven watermelon cultivars, a triploid line (Tri-X313 ) and 16 PIs of C. lanatus var. lanatus; 10 $C$. lanatus var. citroides PIs; and eight $C$. colocynthis PIs. Seeds of all PIs were obtained from the USDA, ARS, Plant Genetic Resources Conservation Unit (Griffin, Ga.). Seeds of 'Charleston Gray' (NSL-5267) were obtained from the USDA, ARS, National Seed Storage Laboratory, Fort Collins, Colo. Seeds of 'Florida Giant', 'Crimson Sweet', 'Mickylee', 'Minilee', and the triploid line Tri-X-313 were provided by Hollar Seeds (Rocky Ford, Colo.). Seeds of 'Sugar Baby' and 'Petite Sweet' were provided by Sunseeds (Woodland, Calif.). Four plants of each accession and six of each cultivar were germinated and grown in a greenhouse. The plants were treated as needed with pesticides [aerosol bombs of nicotine (M/Urvakunj Nicotine Industries, India) and orthene (Whitmire Research Lab., St. Louis), Morestan ${ }^{\circledR}$ (Mobay Corp., Kansas City, Mo.), and malathion Dragon Corp., Roanoke, Va.)] to control twospotted spider mites (Tetranychus urticae Koch) and whiteflies.

Choice bioassay. Nine sequential trials that consisted of adult counts were conducted in randomized open-choice bioassays; eggs were also counted in five of these trials. Four plants of each PI and six plants of each cultivar were used in each assay. In each of these trials, a leaf (from the $4^{\text {th }}$ node from the apex of the vine) from each of the four to six plants of each PI or cultivar was included. Upon leaf removal, the petiole was inserted in a plastic green floral wick (Syndicate Sales, Kokomo, Ind.) containing deionized water. Each leaf was then examined for the presence of whitefly eggs with the aid of a microscope. Although rarely found, any whitefly eggs were removed. The floral wicks, each containing a single leaf sample, were randomly placed ( 8 $\mathrm{cm}$ apart) in holes cut in the bottom side of black plastic trays. The trays with leaves were centered in a small controlled environment room $(3.4 \times 1.8 \times 2.1 \mathrm{~m}$ high $)$. The conditions of the room were continuous overhead lighting (by cool-white fluorescent fixtures with 350 lux at leaf sample height as measured with a LI-COR LI 185B photometer; Lincoln, Nebr.), $26{ }^{\circ} \mathrm{C}$ and $\approx 80 \%$ relative humidity $(\mathrm{RH})$. All leaves were in a horizontal position, 
at the same height, and oriented toward the same direction. Three collard (Brassica oleracea var. acephala L.) plants carrying immature and adult whiteflies from the colony were placed at each end of the room. After 24 $\mathrm{h}$, the number of adult whiteflies was counted on both surfaces of each Citrullus leaf. Following the count on each leaf, the adults were aspirated from the leaf to prevent any additional oviposition. After adults were counted on all leaves on a tray, the tray was removed from the room. After the adult counts were done on all trays, the leaves were rechecked, and any stray whitefly was aspirated. Whitefly eggs were counted on both leaf surfaces using a microscope, and leaf area was determined with a leaf area meter (model 3000; LI-COR, Lincoln, Nebr.). For two trials, numbers of eggs on the two surfaces of each leaf were recorded separately.

No-choice bioassays. A no-choice bioassay for whitefly oviposition was conducted with all PIs and cultivars. A leaf from each of the 4-6 plants of all PIs and cultivars was detached and placed in a water wick as described in the choice experiment. Each leaf was set up in a petri dish arena (modification of illustration in Simmons, 1994). A piece of cotton was spread near the lower quarter of a petri dish lid, and the cotton was moistened with deionized water. A single leaf was placed in the lid of the petri dish with its lower surface turned upward while the petiole was inserted (through a hole drilled in the side of the petridish lid) in a floral wick containing deionized water. To reduce any visual effect of leaf size on whitefly behavior, a standard leaf area was exposed in all petri dishes. A filter paper (15 $\mathrm{cm}$ diameter) placed in the lid and over the leaf was folded to expose a distance of $3 \mathrm{~cm}$ from the side of the lid where the leaf was located. The bottom of a $2.2 \mathrm{~cm}$ deep petri dish was placed within the lid. The bottom of the dish contained a 1.9-cm-diameter opening which was centered over the basal section of the leaf. An additional petri dish lid was placed on top of the petri dish. A 5-mm-diameter hole was drilled in the center of the top petri dish lid to facilitate the introduction of whiteflies. The test arena consisted of the area within the petri dish, and only the 1.9-cm-diameter opening of leaf was exposed to the arena. The exposed leaf was examined for any pre-test whitefly eggs with a microscope and the data were recorded. Twenty adult female $B$. tabaci were aspirated from collard plants in the greenhouse colony and were placed in each test arena through the hole drilled in the lid. Afterwards, the hole was plugged with cotton. The test arenas with leaves were placed upright in an environmental chamber and held in the dark at $25^{\circ} \mathrm{C}$. After $20 \mathrm{~h}$, the eggs on each leaf were counted using a microscope. The number of any pre-test eggs were subtracted from the count at the end of the test. After the first trial, the test arenas were placed horizontally in the environmental chamber with the lower leaf surface facing upward, and the floral wicks were removed once the samples were placed into the experimental chamber. This experiment was repeated five times.
Table 1. Choice test among leaves of Citrullus sp. exposed to B-biotype B. tabaci $\left(26^{\circ} \mathrm{C}\right)$.

\begin{tabular}{lcccc}
\hline \hline Plant & \multicolumn{4}{c}{ Mean no. } \\
\cline { 2 - 5 } taxonomy & Eggs/leaf & Eggs/ $\mathrm{cm}^{2}$ & Adults/leaf & Adults $/ \mathrm{cm}^{2}$ \\
\hline C. var. lanatus & $42.2 \mathrm{a}$ & $2.4 \mathrm{a}$ & $13.1 \mathrm{a}$ & $0.73 \mathrm{a}$ \\
C. var. citroides & $17.6 \mathrm{~b}$ & $1.8 \mathrm{a}$ & $8.9 \mathrm{~b}$ & $0.77 \mathrm{a}$ \\
C. colocynthis & $6.5 \mathrm{~b}$ & $0.6 \mathrm{~b}$ & $3.4 \mathrm{c}$ & $0.29 \mathrm{~b}$ \\
\hline
\end{tabular}

${ }^{2}$ Represented by 24 entries of $C$. lanatus var. lanatus, 10 accessions of $C$. lanatus var. citroides, and eight accessions of $C$. colocynthis, respectively. Means in a column and followed by different letters are significantly different $(P<0.05)$ according to Duncan's multiple range test.
An additional no-choice bioassay on whitefly oviposition was conducted on selected germplasm. Eight PIs (PI 220778, PI 248178, PI 386015, PI 386018, PI 386024, PI 482246, PI 518611, PI 542119), and two cultivars ('Charleston Gray' and 'Mickylee') were selected for the no-choice bioassay. These PIs and cultivars were selected based on their levels of susceptibility or resistance in the choice experiment. This experiment was repeated six times.
Leaf trichome densities. Leaves from one trial of the above choice bioassay on all genotypes were frozen and the trichome densities on both leaf surfaces of each leaf were counted from different portions of the leaf. Trichome densities were determined for the mid-rib (a $6.5-\mathrm{mm}$ section of the middle of the leaf) and for the leaf blade. On the leaf blade, the number of trichomes were counted in three $5.8-\mathrm{mm}^{2}$ areas (the basal, middle, and terminal) of both leaf surfaces using a microscope.
Table 2. Choice and no-choice laboratory tests with Citrullus PIs for adult presence and oviposition by B-biotype Bemisia tabaci.

\begin{tabular}{|c|c|c|c|c|}
\hline \multirow[b]{2}{*}{ Entry } & \multirow{2}{*}{$\begin{array}{c}\text { Plant } \\
\text { taxonomy } \\
\text { group }^{\mathrm{z}} \\
\end{array}$} & \multicolumn{2}{|c|}{ Choice } & \multirow{2}{*}{$\begin{array}{c}\text { No-choice } \\
\text { Mean no. eggs on } \\
1.7 \mathrm{~cm}^{2} \text { exposed area }\end{array}$} \\
\hline & & $\begin{array}{l}\text { Mean no. } \\
\text { eggs } / \mathrm{cm}^{2}\end{array}$ & $\begin{array}{c}\text { Mean no. } \\
\text { adults } / \mathrm{cm}^{2}\end{array}$ & \\
\hline 518611 & $\mathrm{~L}$ & $4.38 \mathrm{a}$ & $0.93 \mathrm{~b}-\mathrm{f}$ & $3.67 \mathrm{~d}-\mathrm{g}$ \\
\hline 560901 & $\mathrm{~L}$ & $4.27 \mathrm{a}$ & $1.30 \mathrm{~b}$ & $5.47 \mathrm{~b}-\mathrm{f}$ \\
\hline 192937 & $\mathrm{~L}$ & $3.69 \mathrm{ab}$ & $1.00 \mathrm{~d}-\mathrm{e}$ & $4.63 \mathrm{c}-\mathrm{g}$ \\
\hline 203551 & $\mathrm{~L}$ & $3.55 \mathrm{ab}$ & $0.91 \mathrm{~d}-\mathrm{g}$ & $1.67 \mathrm{~d}-\mathrm{g}$ \\
\hline G12336 & $\mathrm{L}$ & $3.34 \mathrm{a}-\mathrm{c}$ & $0.89 \mathrm{~b}-\mathrm{g}$ & $2.65 \mathrm{~d}-\mathrm{g}$ \\
\hline Florida Giant & $\mathrm{L}$ & $3.19 \mathrm{a}-\mathrm{c}$ & $0.81 \mathrm{f}-\mathrm{g}$ & $3.54 \mathrm{~d}-\mathrm{g}$ \\
\hline 525099 & $\mathrm{~L}$ & $3.16 \mathrm{a}-\mathrm{c}$ & $1.14 \mathrm{bc}$ & $2.44 \mathrm{~d}-\mathrm{g}$ \\
\hline 189317 & $\mathrm{~L}$ & $3.05 \mathrm{a}-\mathrm{c}$ & $0.73 \mathrm{~b}-\mathrm{g}$ & $2.82 \mathrm{~d}-\mathrm{g}$ \\
\hline 270550 & $\mathrm{~L}$ & $2.81 \mathrm{a}-\mathrm{c}$ & $0.89 \mathrm{~b}-\mathrm{g}$ & $3.67 \mathrm{~d}-\mathrm{g}$ \\
\hline 270306 & $\mathrm{~L}$ & $2.79 \mathrm{a}-\mathrm{c}$ & $0.76 \mathrm{~b}-\mathrm{g}$ & $2.17 \mathrm{~d}-\mathrm{g}$ \\
\hline 271778 & $\mathrm{~L}$ & $2.67 \mathrm{a}-\mathrm{c}$ & $1.07 \mathrm{~b}-\mathrm{d}$ & $3.90 \mathrm{~d}-\mathrm{g}$ \\
\hline Mickylee & $\mathrm{L}$ & $2.54 \mathrm{a}-\mathrm{c}$ & $0.61 \mathrm{~b}-\mathrm{g}$ & $3.70 \mathrm{~d}-\mathrm{g}$ \\
\hline 165451 & $\mathrm{~L}$ & $2.08 \mathrm{a}-\mathrm{c}$ & $0.58 \mathrm{c}-\mathrm{g}$ & $4.75 c-f$ \\
\hline Minilee & $\mathrm{L}$ & $2.40 \mathrm{a}-\mathrm{c}$ & $0.63 \mathrm{~b}-\mathrm{g}$ & $4.62 \mathrm{c}-\mathrm{g}$ \\
\hline Crimson Sweet & $\mathrm{L}$ & $2.27 \mathrm{a}-\mathrm{c}$ & $0.77 \mathrm{~b}-\mathrm{g}$ & $2.93 \mathrm{~d}-\mathrm{f}$ \\
\hline Petite Sweet & $\mathrm{L}$ & $2.20 \mathrm{a}-\mathrm{c}$ & $0.73 \mathrm{~b}-\mathrm{g}$ & $2.77 \mathrm{~d}-\mathrm{f}$ \\
\hline 186975 & $\mathrm{~L}$ & $1.61 \mathrm{a}-\mathrm{c}$ & $0.63 \mathrm{~b}-\mathrm{g}$ & $1.80 \mathrm{~d}-\mathrm{g}$ \\
\hline 249010 & $\mathrm{~L}$ & $1.54 \mathrm{a}-\mathrm{c}$ & $0.55 \mathrm{c}-\mathrm{g}$ & $3.15 \mathrm{~d}-\mathrm{g}$ \\
\hline 189316 & $\mathrm{~L}$ & $1.42 \mathrm{a}-\mathrm{c}$ & $0.44 \mathrm{c}-\mathrm{g}$ & $3.10 \mathrm{~d}-\mathrm{g}$ \\
\hline Charleston Grey & $\mathrm{L}$ & $1.38 \mathrm{a}-\mathrm{c}$ & $0.54 \mathrm{c}-\mathrm{g}$ & $2.62 \mathrm{~d}-\mathrm{g}$ \\
\hline Sugar Baby & $\mathrm{L}$ & $1.37 \mathrm{a}-\mathrm{c}$ & $0.54 \mathrm{c}-\mathrm{g}$ & $2.23 \mathrm{~d}-\mathrm{g}$ \\
\hline 482374 & $\mathrm{~L}$ & $1.27 \mathrm{a}-\mathrm{c}$ & $0.42 \mathrm{c}-\mathrm{g}$ & $4.20 \mathrm{~d}-\mathrm{g}$ \\
\hline Tri-X-313 & $\mathrm{L}$ & $1.07 \mathrm{bc}$ & $0.60 \mathrm{~b}-\mathrm{g}$ & $4.78 \mathrm{c}-\mathrm{f}$ \\
\hline 248178 & $\mathrm{~L}$ & $0.67 \mathrm{bc}$ & $0.29 \mathrm{e}-\mathrm{g}$ & $1.53 \mathrm{e}-\mathrm{g}$ \\
\hline 482302 & $\mathrm{C}$ & $4.26 \mathrm{bc}$ & $2.82 \mathrm{a}$ & $6.00 \mathrm{~b}-\mathrm{e}$ \\
\hline 179881 & $\mathrm{C}$ & $3.17 \mathrm{bc}$ & $0.98 \mathrm{~b}-\mathrm{d}$ & $3.20 \mathrm{~d}-\mathrm{g}$ \\
\hline 482286 & $\mathrm{C}$ & $3.10 \mathrm{bc}$ & $0.79 \mathrm{~b}-\mathrm{g}$ & $5.80 \mathrm{~b}-\mathrm{e}$ \\
\hline 299379 & $\mathrm{C}$ & $2.29 \mathrm{bc}$ & $1.09 \mathrm{~b}-\mathrm{d}$ & $9.40 \mathrm{ab}$ \\
\hline 542119 & $\mathrm{C}$ & $1.60 \mathrm{bc}$ & $0.37 \mathrm{~d}-\mathrm{g}$ & $8.60 \mathrm{a}-\mathrm{c}$ \\
\hline 482331 & $\mathrm{C}$ & $1.36 \mathrm{bc}$ & $0.69 \mathrm{~b}-\mathrm{g}$ & $3.33 \mathrm{~d}-\mathrm{g}$ \\
\hline 402302 & $\mathrm{C}$ & $1.26 \mathrm{bc}$ & $0.49 \mathrm{c}-\mathrm{g}$ & $3.60 \mathrm{~d}-\mathrm{g}$ \\
\hline 482246 & $\mathrm{C}$ & $0.77 \mathrm{bc}$ & $0.65 \mathrm{~b}-\mathrm{g}$ & $11.60 \mathrm{a}$ \\
\hline 482277 & $\mathrm{C}$ & $0.73 \mathrm{bc}$ & $0.85 \mathrm{~b}-\mathrm{g}$ & $6.40 \mathrm{~b}-\mathrm{d}$ \\
\hline 244017 & $\mathrm{C}$ & $0.72 \mathrm{bc}$ & $0.61 \mathrm{~b}-\mathrm{g}$ & $3.00 \mathrm{~d}-\mathrm{g}$ \\
\hline 220778 & $\mathrm{O}$ & $0.80 \mathrm{bc}$ & $0.25 \mathrm{fg}$ & $0 \mathrm{~g}$ \\
\hline 195927 & $\mathrm{O}$ & $0.78 \mathrm{bc}$ & $0.41 \mathrm{~d}-\mathrm{g}$ & $2.50 \mathrm{~d}-\mathrm{g}$ \\
\hline 525083 & $\mathrm{O}$ & $0.72 \mathrm{bc}$ & $0.39 \mathrm{~d}-\mathrm{g}$ & $1.47 \mathrm{e}-\mathrm{g}$ \\
\hline 388770 & $\mathrm{O}$ & $0.64 \mathrm{bc}$ & $0.32 \mathrm{e}-\mathrm{g}$ & $3.90 \mathrm{~d}-\mathrm{g}$ \\
\hline 269365 & $\mathrm{O}$ & $0.57 \mathrm{bc}$ & $0.25 \mathrm{fg}$ & $3.00 \mathrm{~d}-\mathrm{g}$ \\
\hline 386024 & $\mathrm{O}$ & $0.50 \mathrm{bc}$ & $0.24 \mathrm{fg}$ & $1.00 \mathrm{fg}$ \\
\hline 386018 & $\mathrm{O}$ & $0.35 \mathrm{c}$ & $0.19 \mathrm{~g}$ & $3.00 \mathrm{~d}-\mathrm{g}$ \\
\hline 386015 & $\mathrm{O}$ & $0.23 \mathrm{c}$ & $0.27 \mathrm{e}-\mathrm{g}$ & $2.00 \mathrm{~d}-\mathrm{g}$ \\
\hline
\end{tabular}

"Plant taxonomy are: $\mathrm{L}=$ Citrullus lanatus var. lanatus, $\mathrm{C}=C$. lanatus var. citroides, and $\mathrm{O}=$ C. colocynthis. Means in a column and followed by different numbers are significantly different $(P<0.05)$ according to Duncan's multiple range test. 
Survival bioassay. A test was conducted on survival of immatures of $B$. tabaci on each of the above-mentioned 10 selected resistant and susceptible genotypes. Percentage of whitefly survival was determined for the period from the egg stage to adult emergence. Greenhouse-grown plants were taken to the laboratory and whitefly-free $4^{\text {th }}$ node leaves from the apex were used in the study. A leaf on each plant, while still attached to the vine, was placed in a $15.0 \times 2.5-\mathrm{cm}$ plastic petri dish. A U-shaped opening for the stem of the plant was in the side of the petri dish. A 5-mm entrance hole was drilled in the lid $\approx 2 \mathrm{~cm}$ from the edge and opposite the U-shaped opening. Cotton was used to fill the U-shaped opening to prevent mechanical injury to the stem and to prevent the whiteflies from escaping. Twenty adult female B. tabaci were aspirated from collard in the greenhouse colony and were released into each cage arena through the entrance hole. The hole was plugged with cotton. The cages were held at $25^{\circ} \mathrm{C}$ and continuous light for $24 \mathrm{~h}$. Subsequently, all adult whiteflies were aspirated from the leaves. With the aid of a microscope, all eggs were removed from the upper surface of each test leaf. The number of eggs on the lower leaf surface was recorded for each test leaf. The test leaves were tagged with identification numbers and the plants were moved to a climate-controlled room $\left(26^{\circ} \mathrm{C}, 16: 8 \mathrm{LD}, 40 \%\right.$ to $60 \% \mathrm{RH})$. Illumination was by fluorescent lighting (40-W cool-white and 40-W Vitalite $^{\circledR}$, Duro-test ${ }^{\circledR}$, Power-Twist ${ }^{\circledR}$; Duro Test, Fairfield, N.J.) located $\approx 35 \mathrm{~cm}$ above the plants. The number of adults which successfully emerged from a given leaf was based on counts of the empty exuvia of the pupa stage. Percentage of survival to the adult stage was based on the number of empty exuvia relative to the number of eggs from the beginning of the test. Whitefly survival was tested on two to eight leaves per genotype. This experiment was conducted one time.

The data were analyzed with SAS computations (SAS Institute, 1994). Means were separated using the Duncan's multiple range test and the level of significance was based on $P=0.05$. All percentage data were transformed using arcsine transformation before analysis.

\section{Results and Discussion}

Whitefly adults and eggs were observed on all of the PIs and cultivars. The number of adults on the leaves was positively correlated $(P<0.0001 ; r=0.75)$ with the number of eggs laid. As a group, the C. lanatus var. lanatus PIs and cultivars were most favorable, while the C. colocynthis PIs were least favorable to whiteflies in the choice tests (Table 1). The taxonomic groups had a significant effect on density of whitefly adults ( $\mathrm{F}=19.35$; $\mathrm{df}=2$, 1,223; $P<0.0001)$ and density of eggs $(\mathrm{F}=$ 17.47; $\mathrm{df}=2,694 ; P<0.0001)$. Numbers of whitefly adults and eggs varied widely within each of the three groups of Citrullus germplasm (Table 2). Egg density on leaves ranged from 0.67 to $4.38 \mathrm{eggs} / \mathrm{cm}^{2}$ on C. lanatus var. lanatus,
$0.72-4.26$ eggs $/ \mathrm{cm}^{2}$ on C. lanatus var. citroides, and $0.23-0.80 \mathrm{eggs} / \mathrm{cm}^{2}$ on $C$. colocynthis (Table 2). Adult density within each group generally followed that for egg density; 0.29-1.30, 0.37-2.82, and 0.19-0.41 adults $/ \mathrm{cm}^{2}$, respectively (Table 2 ). In the choice bioassay that included all cultivars and PIs, the density of eggs $(\mathrm{F}=11.5 ; \mathrm{df}=2$, $670 ; P<0.0001)$ was affected by the taxonomic groups of Citrullus (Table 3 ). The lowest egg density was among the $C$. colocynthis PIs (Tables 2 and 3). A similar trend was observed in the no-choice bioassay which consisted of an evaluation of eight PIs and two cultivars (Table 3).

In our no-choice experiment, only a small basal area $\left(1.7 \mathrm{~cm}^{2}\right)$ of the lower leaf surface was exposed to whiteflies. In a previous study, whiteflies (B. tabaci) readily deposited eggs on both leaf-surfaces of watermelon plants, and $59 \%$ of the eggs were on the lower surface in a laboratory choice test (Simmons, 1994). In that study, $88 \%$ of the eggs were laid on the lower surface in greenhouse trials while $73 \%$ to $100 \%$ of eggs were laid on the lower leaf surface in field trials. In our choice assay, comparable proportions of eggs on the lower leaf surface of $C$. lanatus var. lanatus, C. lanatus var. citroides, and C. colocynthis $(85 \%, 80 \%$, and $80 \%$, respectively) were observed. Because most of the eggs were found on the lower surface, any influence from trichome density may be most important on that surface. Research on several other crops, notably cotton (Gossypium sp.), have shown an association of whitefly infestation with trichome density. A low trichome density or the absence of trichomes can result in reduced whitefly infestation (Butler and Henneberry, 1984). Similarly, a high trichome density can result in a reduced infestation (Snyder et al., 1998). In our study, no distinction was made on trichome type, although there was much variation in length. Among the three taxonomic groups, $C$. colocynthis had the greatest densities of trichomes on the lower surface (Table 4). No attempt was made to determine the mechanism of resistance to whiteflies in this study. However, the data suggest that density of trichomes may play a role in resistance to whiteflies, although other factors may also be important in the resistance. Whiteflies survived to the adult stage on all plants selected for this assay (Table 3). Mortalities were observed among the nymphal instars and the pupal stage, but data were not recorded for these groups. Because the first nymphal instar, crawler stage, is active, a few moved to and developed on the upper surface of some leaves, but data were not recorded by leaf surface. In concert with the resistance observed in the other assays, survival was lowest on the $C$. colocynthis leaves compared with the other two taxonomic groups (Table 3 ). Although the same leaf position was used among plants, leaf age might differ because of possible differences in plant growth rates. We had previously noticed that leaves that are even several weeks older than the test leaves were highly acceptable to whitefly infestation. All leaves tested in this study were distinctively young. Furthermore, the whitefly infestation results are consistent with our general observations of whitefly infestations on Citrullus accessions.

Our data indicate that among the three Citrullus groups evaluated, PIs of $C$. colocynthis are the least favorable to B-biotype B. tabaci for feeding, oviposition, and survival from egg to the adult stage. Citrullus colocynthis has the broadest geographical distribution among the Citrullus species (Zamir et al., 1984). It is found in North Africa (PI 388770 was collected in Morocco, and PI 525083 was collected in Egypt), and in South-Central Asia (PI 386015, PI 386018, and PI 386024 were collected in Iran, while PI 220778 and PI 195927 were collected in Afghanistan).

Table 3. Mean number of B-biotype B. tabaci eggs on $1.7 \mathrm{~cm}^{2}$ of leaf area of Citrullus sp. exposed to whiteflies in a choice test, and percentage of survival of the whiteflies from egg to the adult stage $\left(26^{\circ} \mathrm{C}\right)$.

\begin{tabular}{lcccc}
\hline \hline Plant & \multicolumn{2}{c}{ All entries } & & \multicolumn{2}{c}{10 select entries } \\
\cline { 2 - 2 } \cline { 5 - 5 } taxonomy & Mean no. of eggs & & Mean no. of eggs & $\%$ survival \\
\hline C. var. lanatus & $3.3 \mathrm{~b}$ & $5.2 \mathrm{a}$ & $60.1 \mathrm{a}$ \\
C. var. citroides & $5.4 \mathrm{a}$ & & $6.6 \mathrm{a}$ & $52.1 \mathrm{ab}$ \\
C. colocynthis & $2.4 \mathrm{~b}$ & & $2.2 \mathrm{~b}$ & $36.6 \mathrm{~b}$
\end{tabular}

${ }^{2}$ Represented by 24 germplasms of Citrullus lanatus var. lanatus, 10 accessions of C. lanatus var. citroides, and eight accessions of $C$. colocynthis, respectively; among the 10 selected entries, four are C. lanatus var. lanatus, two are C. lanatus var. citroides, and four are $C$. colocynthis. Means in a column and followed by different numbers are significantly different $(P<0.05)$ according to Duncan's multiple range test.

Table 4. Trichome density of $4^{\text {th }}$ leaf position from apex of different groups of Citrullus.

\begin{tabular}{|c|c|c|c|c|c|c|c|c|c|}
\hline \multirow{2}{*}{$\begin{array}{l}\text { Plant } \\
\text { taxonomy }\end{array}$} & \multicolumn{4}{|c|}{$\begin{array}{l}\text { Trichome density on upper } \\
\text { leaf surface }\left(\text { mean no. } / \mathrm{mm}^{2}\right)^{\mathrm{y}}\end{array}$} & \multicolumn{4}{|c|}{$\begin{array}{l}\text { Trichome density on lower } \\
\text { leaf surface }\left(\text { mean no. } / \mathrm{mm}^{2}\right)^{y}\end{array}$} & \multirow{2}{*}{$\begin{array}{l}\text { Total no. } \\
\text { trichomes } \\
\end{array}$} \\
\hline & Mid-rib & Basal & Central & Terminal & Mid-rib & Basal & Central & Terminal & \\
\hline C. var. lanatus & $2.6 \mathrm{~b}$ & $7.5 \mathrm{a}$ & $7.6 \mathrm{a}$ & $6.9 \mathrm{a}$ & $3.9 \mathrm{~b}$ & $17.9 \mathrm{~b}$ & $18.3 \mathrm{~b}$ & $17.2 \mathrm{~b}$ & $417.1 \mathrm{~b}$ \\
\hline C. var. citroides & $3.8 \mathrm{~b}$ & $9.9 \mathrm{a}$ & $9.7 \mathrm{a}$ & $7.8 \mathrm{a}$ & $5.0 \mathrm{~b}$ & $25.1 \mathrm{a}$ & $25.3 \mathrm{a}$ & $22.0 \mathrm{~b}$ & $636.0 \mathrm{ab}$ \\
\hline C. colocynthis & $5.9 \mathrm{a}$ & $8.7 \mathrm{a}$ & $8.4 \mathrm{a}$ & $9.1 \mathrm{a}$ & $8.5 \mathrm{a}$ & $31.4 \mathrm{a}$ & $30.0 \mathrm{a}$ & $29.6 \mathrm{a}$ & $758.6 \mathrm{a}$ \\
\hline
\end{tabular}

${ }^{\mathrm{z}}$ Represented by 24 entries of Citrullus lanatus var. lanatus, 10 accessions of C. lanatus var. citroides, and eight accessions of $C$. colocynthis, respectively.

${ }^{y}$ Means in a column and followed by different letters are significantly different $(P<0.05)$ according to Duncan's multiple range test.

${ }^{\mathrm{x}}$ Number of trichomes in all sampled areas $\left(5.8-\mathrm{mm}^{2}\right.$ areas of leaf blade and $6.5-\mathrm{mm}$ section of mid-rib) per leaf. 
Citrullus colocynthis does not have the desirable horticultural traits of $C$. lanatus. It has small, globular, bitter fruits with toxic properties (Elawad et al., 1984; Goldfain et al., 1989), but it also contains compounds toxic to insects (el-Naggar et al., 1989). Wide genetic diversity exists among $C$. colocynthis PIs (Levi et al., 2000), which indicates that this species may contain various genes that could confer pest resistance in cultivated watermelon. Host plant resistance to insects is a valuable tool to manage insect pests. However, only a few cucurbit breeding lines and one cultivar with insect resistance were developed in recent years (Webb, 1998). Currently, $F_{2}$ populations ('Charleston Gray' x PI 386024) are being produced and will be used to determine the mode of inheritance of whitefly resistance in watermelon.

\section{Literature Cited}

Brown, J.K., D.R. Frohlich, and R.C. Rosell. 1995. The sweetpotato or silverleaf whiteflies: Biotypes of Bemisia tabaci or a species complex? Annu. Rev. Entomol. 40:511-534.

Burkill, H.M. 1985. The useful plants of west tropical Africa. Vol. 1. $2^{\text {nd }}$ ed. Royal Botanic Gardens, Kew, U.K.

Butler, G.D., Jr., and T.J. Henneberry. 1984. Bemisia tabaci: Effect of cotton leaf pubescence on abundance. Southwest Entomologist 9:91-94.

Cock, M.J.W. 1993. Bemisia tabaci an update 1986-1992 on the cotton whitefly with an annotated bibliography. CAB, Ascot, U.K.

De Winter, B. 1990. A new species of Citrullus (Benincaseae) from the Namibia desert, Namibia. Bothalia 20:209-211.

Elawad, A.A., E.M. Abdel Bari, O.M. Mahmoud, and S.E.I. Adam. 1984. The effect of Citrullus colocynthis on sheep. Vet. Human Toxicol. 6:481-485

el-Naggar, M.E., M.M. Abdel-Sattar, and S.S. Mosallam. 1989. Toxicity of colocynithin and hydrated colocynithin from alcohol extract of
Citrullus colocynthis pulp. J. Egypt. Soc. Parasitol. 1:179-185.

Ghong, Y. 1969. Host plant morphological variation of Bemisia tabaci (Gennadius) (Homoptera: Aleyrodidae) in Taiwan. Plant Prot. Bul. (Taiwan) 2:23-32.

Goldfain, D., A. Lavergne, A. Galian, L. Chauveinc, and F. Prudhomme. 1989. Peculiar acute toxic colitis after ingestion of colocynth: A clinicopathological study of three cases. Gut 30:14121418.

Greathead, A. H. 1986. Host plants, p. 17-25. In M.J.W. Cock (ed.). Bemisia tabaci-A literature survey on the cotton whitefly with an annotated bibliography. CAB, Ascot, U.K.

Jarret, R.L., L.C. Merrick, T. Holms, J. Evans, and M.K. Aradhya. 1997. Simple sequence repeats in watermelon [Citrullus lanatus (Thunb.) Matsum. \& Nakai]. Genome 40:433-441.

Lazarre, M. and D. Gerling. 1993. The population dynamics of natural enemies of Bemisia tabaci in cotton fields and the influence of insecticide sprays. Phytoparasitica 21:171-172.

Levi, A., C.E. Thomas, A.P. Keinath, and T.C. Wehner. 2000. Estimation of genetic diversity among Citrullus accessions using RAPD markers. Acta Horticulturae 510:385-390.

McAuslane, H.J., S.E. Webb, and G.W. Elmstrom. 1996. Resistance in germplasm of Cucurbita pepo to silverleaf, a disorder associated with Bemisia argentifolii (Homoptera: Aleyrodidae). Florida Entomol. 79:206-221.

Meeuse, A.D. 1962. The Cucurbitaceae of Southern Africa. Bothalia 8:1-111.

Perring, T.M., A.D. Cooper, R.J. Rodriguez, C.A. Farrar, and T.S. Bellows, Jr. 1993. Identification of a whitefly species by geonomic and behavioral studies. Science 259:74-77.

Riley, D., D. Batal, and D. Wolff. 2001. Resistance in glabrous-type Cucumis melo L. to whiteflies (Homoptera: Aleyrodidae). J. Entomol. Sci. 36:46-56.

SAS Institute. 1994. SAS/STAT user's guide, version $6,4^{\text {th }}$ ed. SAS Inst., Cary, N.C.

Simmons, A.M. 1994. Oviposition on vegetable by Bemisia tabaci (Homoptera: Aleyrodidae): Temporal and leaf surface factors. Environ. Entomol. 23:381-389.

Simmons, A.M. and D.M. Jackson. 2000. Eval- uation of foliar-applied insecticides on abundance of parasitoids of Bemisia argentifolii (Homoptera: Aleyrodidae) in vegetables. J. Entomol. Sci. 35:1-8.

Simmons, A.M. and J.D. McCreight. 1996. Evaluation of melon for resistance to Bemisia argentifolii (Homoptera: Aleyrodidae). J. Econ. Entomol. 89:1663-1668.

Simmons, A.M., G.S. McCutcheon, R.J. Dufault, R.L. Hassell, and J.W. Rushing. 2000. Bemisia argentifolii (Homoptera: Aleyrodidae) attacking species of medicinal plants. Annals Entomol. Soc. Am. 93:856-861.

Snyder, J.C., A.M. Simmons, and R.R. Thacker. 1998. Attractancy and ovipositional response of adult Bemisia argentifolii (Homoptera: Aleyrodidae) to type IV trichome density on leaves of Lycopersicon hirsutum grown in three day-length regimes. J. Entomol. Sci. 33:270281.

Soria, C., A.I. López-Sesé, and M.L. GómezGuillamón. 1999. Resistance of Cucumis melo against Bemisia tabaci (Homoptera: Aleyrodidae). Environ. Entomol. 28:831-835.

U.S. Department of Agriculture. 1997. Silverleaf whitefly: Five-year national research and action plan: Progress review, technology transfer and new research and action plan (1997-2001). T.J. Henneberry, N. Toscano, R.M. Faust, and D. Koop (eds.). USDA-ARS Publ. 1997-02 (Suppl.).

U.S. Department of Agriculture. 1999. Agricultural Statistics. U.S. Govt. Printing Office, Washington, D.C.

Webb, S.E. 1998. Insect resistance in cucurbits: 1992-98, p. 79-83. In: J.D. McCreight (ed.). Cucurbitaceae 98, Evaluation and enhancement of cucurbit germplasm. ASHS Press, Alexandria, Va.

Wessel-Beaver L. 2000. Inheritance of silverleaf resistance in Cucurbita moschata. Acta Hort. 510:289-295.

Whitaker, T.W., and W.B. Bemis. 1976. Cucurbits, p. 64-69. In: N.W. Simmonds (ed.). Evolution of crop plants. Longman, London.

Zamir, D., N. Navot, and J. Rudich. 1984. Enzyme polymorphism in Citrullus lanatus and $C$. colocynthis in Israel and Sinai. Plant Syst. Evol. 146:163-137. 